\title{
Performance of Different Cultivars in Direct Seeded Rice (Oryza sativa L.) with Various Seeding Densities
}

\author{
Asif Ameen 1,2, Zubair Aslam 1*, Qamar Uz Zaman1, Ehsanullah1, Shahid Ibne Zamir'1, \\ Imran Khan', Muhammad Junaid Subhani ${ }^{3}$ \\ ${ }^{1}$ Department of Agronomy, University of Agriculture, Faisalabad, Pakistan \\ ${ }^{2}$ Department of Agronomy, College of Agronomy \& Biotechnology, China Agricultural University, Beijing, China \\ ${ }^{3}$ Department of Entomology, University of Agriculture, Faisalabad, Pakistan \\ Email: zauaf@hotmail.com
}

Received 4 August 2014; revised 6 September 2014; accepted 27 September 2014

Copyright (C) 2014 by authors and Scientific Research Publishing Inc.

This work is licensed under the Creative Commons Attribution International License (CC BY).

http://creativecommons.org/licenses/by/4.0/

(c) (i) Open Access

\section{Abstract}

Optimum seeding density is necessary to achieve the production potential of a cultivar in all crops. To investigate the performance of different cultivars in direct seeded rice in response to various seeding densities, a field experiment was conducted at Agronomic Research Area, University of Agriculture, Faisalabad during the kharif 2012. Super basmati (fine rice) and KSK-133 (coarse rice) were sown using seeding densities of $30,45,60$ and $75 \mathrm{~kg} \cdot \mathrm{ha}^{-1}$. Results indicated that leaf area index and crop growth rate varied among rice cultivars as well as various seeding densities. The growth of rice at seeding density of $75 \mathrm{~kg} \cdot \mathrm{ha}^{-1}$ was higher than rest of treatments. The response of rice yield and its components like number of productive tillers, number of kernels per panicle and 1000-kernal weight differed significantly under the influence of cultivars and various seeding densities. Seeding density of $75 \mathrm{~kg} \cdot \mathrm{ha}^{-1}$ remained superior for both rice cultivars regarding final yield. This treatment furnished kernel yields of 3.83 and $5.49 \mathrm{t} \cdot \mathrm{ha}^{-1}$ in fine and coarse rice, respectively which were significantly higher than other treatments. However, Kernel quality was improved in terms of lower number of sterile and chalky kernels at lower seeding densities $\left(30 \mathrm{~kg} \cdot \mathrm{ha}^{-1}\right)$. Based on these findings, it is concluded that using seeding density of $75 \mathrm{~kg}^{-h^{-1}}$ for direct seeded fine and coarse rice cultivars is beneficial in terms of better growth and higher yield but kernel quality is reduced by increasing the seeding density.

\section{Keywords}

Seeding Density, Direct Seeded Rice, Leaf Area Index, Kernel Quality

${ }^{*}$ Corresponding author.

How to cite this paper: Ameen, A., et al. (2014) Performance of Different Cultivars in Direct Seeded Rice (Oryza sativa L.) with Various Seeding Densities. American Journal of Plant Sciences, 5, 3119-3128. 


\section{Introduction}

Rice (Oryza sativa L.) is a most important staple food of about half of the world population. Asia is the leader in rice production and accounts for more than $90 \%$ of world rice production [1]. More than $75 \%$ of the world's rice is consumed by people in Asian countries and thus the rice is of great importance for food security in Asia [2]. Rice being globally important food cash crop holds a unique status in Pakistan's agriculture. It is the second most important staple food crop after wheat and third largest cash crop after wheat and cotton in Pakistan. It is an important economic crop and its export accounted for $4.9 \%$ of value added in agriculture and $1 \%$ of GDP. At present, Pakistan is growing rice on an area of $2.57 \mathrm{~m}$ ha with an average yield of $2396 \mathrm{~kg} \cdot \mathrm{ha}^{-1}$ [3]. Traditionally, rice is sown in puddled soils by transplanting 25 - 45 days old seedlings from wet nurseries of rice. Though this approach has been a long-term practiced, it has problems of poor water management in the unleveled areas, scarcity of irrigation water supply and drainage facilities. In addition, less plant population, inefficiency in input management, improper seedbed preparation, late transplanting, unavailability and costly labor during the peak transplanting time and inadequate post-harvest practices are drawbacks of transplanting [4]. Above mentioned scenario necessitates alternative methods of rice production and their feasibility needs to be explored under local agro-ecological conditions. A promising method of rice cultivation is aerobic direct seeding rather than puddling and transplanting rice seedlings [5]. Direct seeding is a substitute of rice transplanting method which requires only two man hours to sow the same area [6]. It requires less water, labor and capital inputs. Seeding density (seed rate) exerts a strapping effect on rice grain yield, because of its aggressive influence firstly in crop growth and development and lastly on rice yields [7]. Without optimum plant population, a cultivar cannot give maximum genetic potential. Optimum plant population contributes to high yield, which relates directly to seeding density [8]. The actual yield of rice in Pakistan is far less than the potential yield realized at different research stations or at the farms of progressive growers. The yield gap of $50 \%-60 \%$ between potential and actual yield at farmer's field is accredited to a number of agronomic constraints of which low plant density per unit area, weed infestation and inappropriate sowing methods are the most important ones and have a direct effect on final yield of rice [9]. It is possible to increase rice yield at farm level by about $50 \%-60 \%$ by obtaining an optimum plant population [10] and [11]. Low seeding rates resulted in lower dry matter and seed yield than the higher seeding rates [12]. The optimum plant population with maximum productive tillers through direct seeding could reduce crop establishment cost. Keeping in view the above facts the research was conducted to evaluate the comparative effects of different seeding densities on growth, yield and quality of fine and coarse rice cultivars and optimize the seed rate to get better stand establishment.

\section{Materials and Methods}

The experiment was conducted at Agronomic Research Area, University of Agriculture, Faisalabad $\left(31.25^{\circ} \mathrm{N}\right.$ latitude, $73.09^{\circ} \mathrm{E}$ longitude, $184 \mathrm{~m}$ above sea level) during kharif 2012. The experiment was laid out in randomized complete block design (RCBD) with factorial arrangement having three replications and net plot size was maintained $2.0 \mathrm{~m} \times 6.0 \mathrm{~m}$. Experimental treatments comprised of two rice cultivars (Super basmati and KSK-133) and four seeding densities (30, 45, 60 and $75 \mathrm{~kg} \cdot h a^{-1}$ ). Seeds of both cultivars were collected from Rice Research Institute Kala Shah Kaku. The Super basmati is fine rice cultivar and it is famous for its fragrance while KSK-133 is coarse rice cultivar. Seeds were soaked in water for 24 hours prior to seeding for better germination and stand establishment. Treated seeds were drilled $3 \mathrm{~cm}$ deep in saturated soil in $20 \mathrm{~cm}$ spaced rows with a single row hand drill on June 14, 2012. A fertilizer dose of 100-67-62 $\mathrm{kg} \mathrm{NPK} \cdot \mathrm{ha}^{-1}$ in the form of Urea, diammonium phosphate (DAP) and murate of potash (MOP) respectively was applied. Whole quantity of DAP and MOP with 1/3rd part of urea was applied prior to seeding as basal dose while the remaining of nitrogen divided in two splits and applied at two critical stages as tillering and panicle initiation. Irrigation was applied when the soil reached at field capacity level. The irrigation was applied with 7 - 10 days gap on water accessibility. For weed control, mixture of Ethoxy sulphuran (Sunstar 15 WG) and Phenoxyprop-p-ethyle (Puma Super $7.5 \mathrm{EW}$ ) at $200 \mathrm{~g}$ and $370 \mathrm{ml} \cdot \mathrm{ha}^{-1}$ respectively was applied and manual weeding was also done at regular intervals in saturated soil. Carbofuran (Furadan $3 \mathrm{G}$ ) was broadcasted at $25 \mathrm{~kg} \cdot \mathrm{ha}^{-1}$ to protect the crop from stem borers and leaf folders. The weather parameters viz., temperature $\left({ }^{\circ} \mathrm{C}\right)$, rainfall $(\mathrm{mm})$, relative humidity $(\%)$ and wind speed $(\mathrm{Km} / \mathrm{h})$ during the study period were recorded on weekly bases. It is represented in Figure 1. Data regarding to growth parameters (leaf area index and crop growth rate), yield related components (plant height, total tillers, productive tillers, kernels per panicle, 1000-kernel weight and grain yield) and quality parameters 


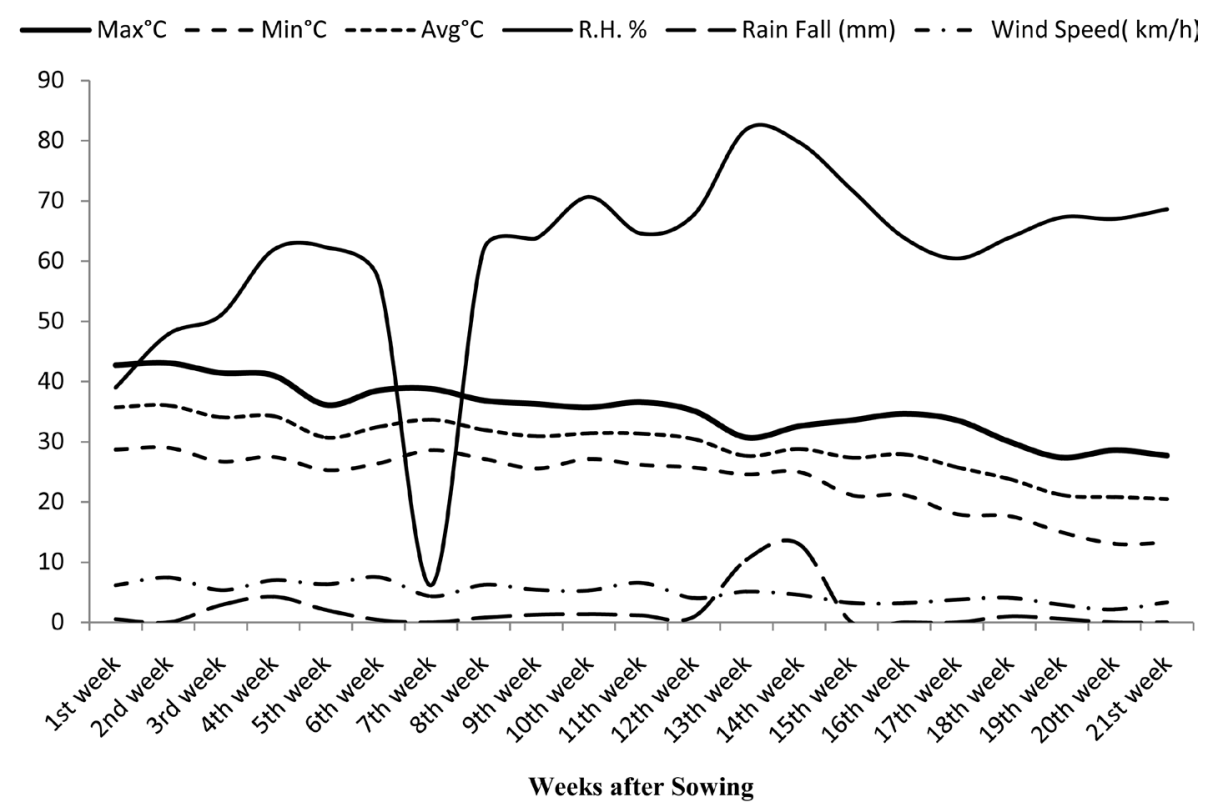

Figure 1. Meteorological data during the kharif 2012 at experimental site. Source: Agricultural Meteorology Cell, Department of Crop Physiology, University of Agriculture, Faisalabad, Pakistan.

(normal kernels and sterile kernels) were recorded using standard procedures. Leaf area and crop growth rate was calculated by using the given equations.

$$
[\mathrm{LAI}=\text { leaf area/ground area }]\left[\mathrm{CGR}=\left(W_{2}-W_{1}\right) /\left(t_{2}-t_{1}\right)\right]
$$

where $W_{1}=$ Total dry matter at the first harvest; $W_{2}=$ Total dry matter at the second harvest; $t_{1}=$ Date of observation of first dry matter; $t_{2}=$ Date of observation of second dry matter. Remaining parameters were recorded using standard procedures and recorded data was analyzed statistically by using Fisher's analysis of variance technique and significant means were separated using least significant difference (LSD) test at 5\% probability level [13].

\section{Results and Discussion}

\subsection{Leaf Area Index (LAI)}

Leaf area index (LAI) showed periodic increase in both rice cultivars as depicted in Figure 2. Such an increase was more pronounced in Super basmati as compared to KSK-133. The maximum leaf area was recorded at 90 DAS which declined thereafter. Increasing seeding density positively influenced the LAI in both of rice cultivars. Among various seeding densities, $\mathrm{S}_{1}\left(30 \mathrm{~kg} \cdot \mathrm{ha}^{-1}\right)$ resulted in lower value of LAI than rest of treatments. At 90 DAS, more LAI (7.22) was noticed in Super basmati than KSK-133 (6.94) at the seeding density of $75 \mathrm{~kg} \cdot \mathrm{ha}^{-1}$. The KSK-133 accumulated lower LAI than Super basmati. [14] Stated that the photosynthetic characters of rice crop were affected by plant population. [15] observed that nitrogen uptake was considerably low at lower plant population as compared to highest plant population. Higher LAI in $\mathrm{S}_{4}$ might be attributable to higher planting density in this treatment. Increasing plant density decreased LAI per plant but increased LAI per unit area, which led to more leaf area development. These results are in consonance with those of [16].

\subsection{Crop Growth Rate (CGR)}

Temporal increase in crop growth rate (CGR) was observed with maximum values achieved at 75 - 90 DAS, which declined substantially as shown in Figure 3. Higher growth rate was recorded by fine rice (Super basmati) as compared to coarse rice (KSK-133). Among various seeding densities, higher CGR was recorded when rice was seeded at $75 \mathrm{~kg} \cdot \mathrm{ha}^{-1}$, which was closely followed by seeding density of 60 and $40 \mathrm{~kg} \cdot \mathrm{ha}^{-1}$. The seeding den- 

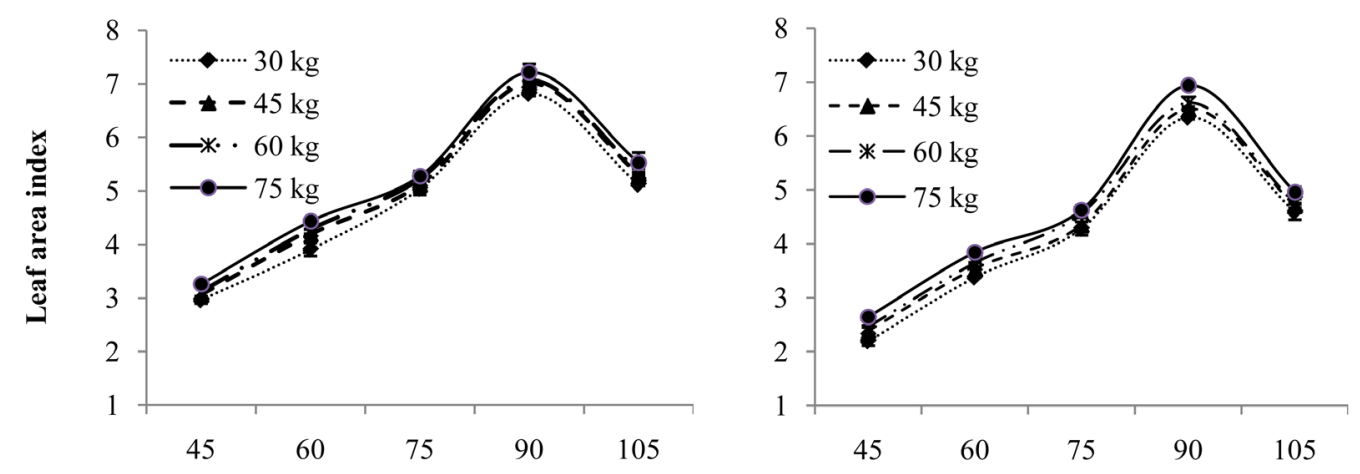

Days after sowing

(a)

(b)

Figure 2. Leaf area index (LAI) as influenced by various seeding densities in direct seeded fine and coarse rice cultivars (a) Super basmati and (b) KSK-133. Vertical bars above mean denote standard error of three replicates.
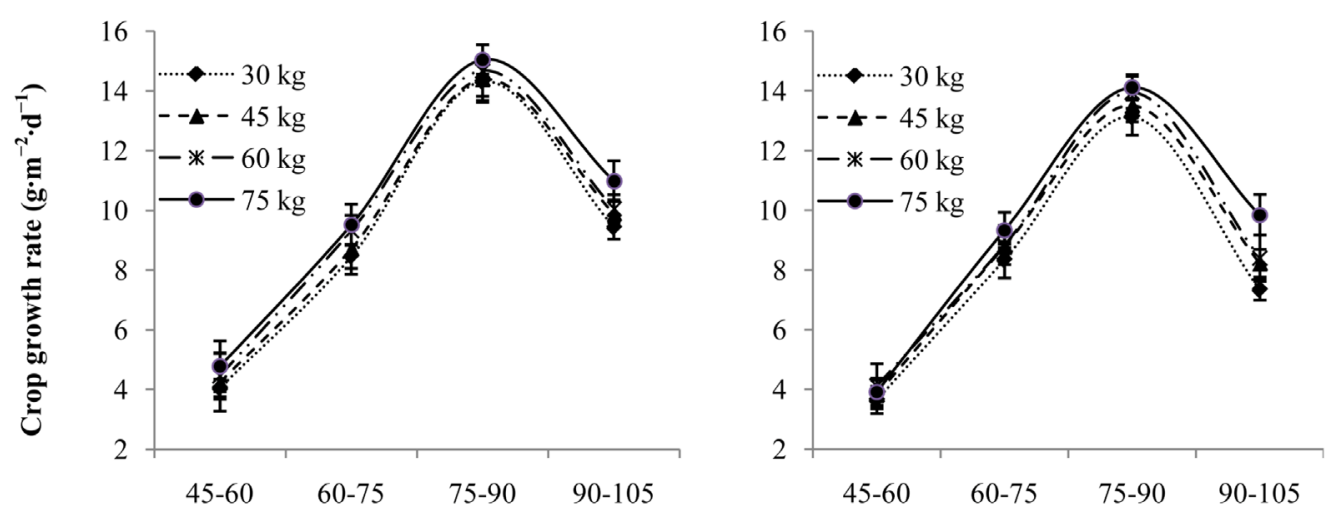

Days after sowing

(a)

(b)

Figure 3. Crop growth rate (CGR) as influenced by various seeding densities in direct seeded fine and coarse rice cultivars (a) Super basmati and (b) KSK-133. Vertical bars above mean denote standard error of three replicates.

sity of $30 \mathrm{~kg} \cdot \mathrm{ha}^{-1}$ recorded lower CGR. Higher crop growth rate in $\mathrm{S}_{4}$ might be attributed to optimal growth conditions that led to vigorous crop stand. Furthermore, less interplant competition at higher rice densities might be a factor for its higher growth rate. Genotypic variation regarding growth rate is due to varying morphology and stature of crop plants.

\subsection{Plant Height}

Plant height is statistically differed among seeding density treatments as represented in Table 1. Maximum plant height $(75.77 \mathrm{~cm})$ which was statistically at par with $S_{3}\left(60 \mathrm{~kg} \cdot \mathrm{ha}^{-1}\right)$ was observed at the seeding density of 75 $\mathrm{kg} \cdot \mathrm{ha}^{-1}\left(\mathrm{~S}_{4}\right)$. While minimum plant height $(72.77 \mathrm{~cm})$ that was statistically at par with $\mathrm{S}_{2}$ was recorded for $\mathrm{S}_{1}$ (30 $\left.\mathrm{kg} \cdot \mathrm{ha}^{-1}\right)$. As for rice cultivars are concerned the KSK-133 showed less plant height $(59.33 \mathrm{~cm})$ as compared to Super basmati which showed plant height $(89.27 \mathrm{~cm})$. There was a weak positive association between plant height and paddy yield having 34\% and 45\% determination coefficient in Super basmati and KSK-133, respectively Figure 4. Increase in plant height with increasing seeding densities might be attributed to higher competition for growth resources especially for light. These results are in consonance with that of [17] who reported an increase in plant height by increasing seeding rate. Whereas, [9] reported that there was non-significant effect of seeding densities on plant height. 

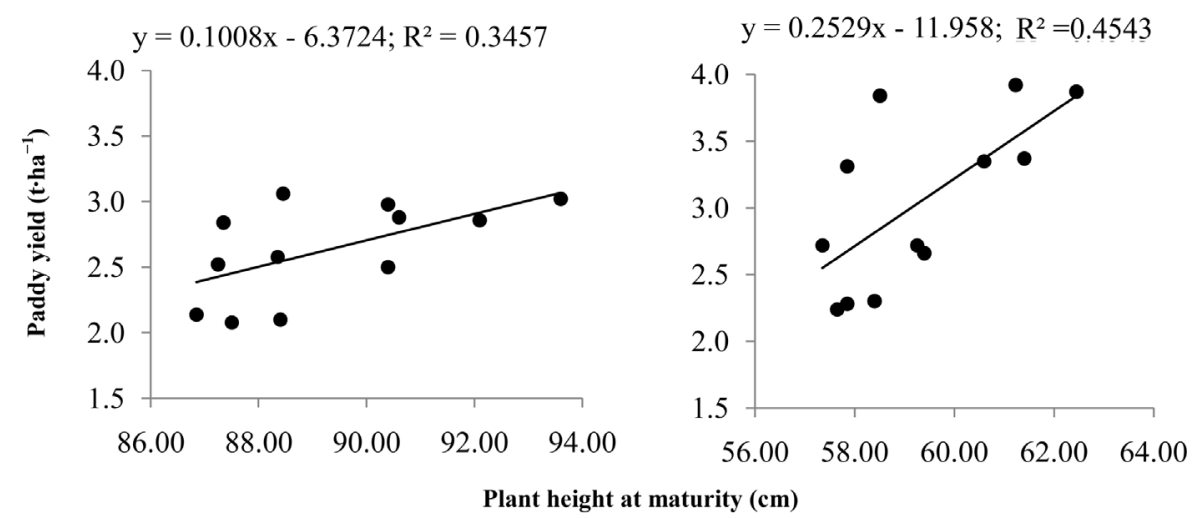

(a)

(b)

Figure 4. Relationship between plant height at maturity $\left(\mathrm{g} \cdot \mathrm{m}^{-2}\right)$ and paddy yield $\left(\mathrm{t} \cdot \mathrm{ha}^{-1}\right)$ in (a) Super basmati and (b) KSK-133.

Table 1. Influence of various seeding densities and cultivars on yield and quality attributes in direct seeded rice.

\begin{tabular}{|c|c|c|c|c|c|c|c|c|}
\hline Treatment & $\begin{array}{l}\text { Plant } \\
\text { height } \\
\text { (cm) }\end{array}$ & $\begin{array}{l}\text { Total number } \\
\text { of tillers }\left(\mathbf{m}^{2}\right)\end{array}$ & $\begin{array}{l}\text { Productive } \\
\text { tillers }\left(\mathbf{m}^{2}\right)\end{array}$ & $\begin{array}{c}\text { Number of } \\
\text { kernels per } \\
\text { panicle }\end{array}$ & $\begin{array}{c}\text { 1000-kernel } \\
\text { weight (g) }\end{array}$ & $\begin{array}{c}\text { Paddy } \\
\text { yield } \\
\left(t \cdot h a^{-1}\right)\end{array}$ & $\begin{array}{c}\text { Sterile } \\
\text { kernels (\%) }\end{array}$ & $\begin{array}{c}\text { Normal } \\
\text { kernels } \\
(\%)\end{array}$ \\
\hline \multicolumn{9}{|c|}{ Seeding densities $\left(\mathrm{kg} \cdot \mathrm{ha}^{-1}\right)$} \\
\hline$S_{1}=30$ & 75.77 a & $244.83 \mathrm{~d}$ & $221.33 \mathrm{~d}$ & 102.43 a & $19.35 \mathrm{a}$ & $3.17 \mathrm{~d}$ & $5.51 \mathrm{c}$ & $63.05 \mathrm{a}$ \\
\hline$S_{2}=45$ & $74.98 \mathrm{ab}$ & 297.17 c & $275.33 \mathrm{c}$ & $97.36 \mathrm{~b}$ & $18.99 \mathrm{ab}$ & $3.73 \mathrm{c}$ & $6.48 \mathrm{~b}$ & $60.46 \mathrm{~b}$ \\
\hline$S_{3}=60$ & $73.67 \mathrm{bc}$ & $350.00 \mathrm{~b}$ & $332.83 \mathrm{~b}$ & 94.49 bc & $18.42 \mathrm{bc}$ & $4.37 \mathrm{~b}$ & $6.86 \mathrm{~b}$ & 59.08 bc \\
\hline$S_{4}=75$ & 72.78 c & 388.67 a & $369.50 \mathrm{a}$ & 91.68 c & $17.93 \mathrm{c}$ & $4.66 \mathrm{a}$ & $7.61 \mathrm{a}$ & $57.75 \mathrm{c}$ \\
\hline LSD & 1.94 & 13.30 & 16.18 & 4.44 & 0.70 & 0.11 & 0.29 & 1.37 \\
\hline \multicolumn{9}{|c|}{ Rice cultivars } \\
\hline$C_{1}=$ Super basmati & 89.27 a & 332.33 a & 313.33 a & 96.98 & $16.44 \mathrm{~b}$ & $3.29 \mathrm{~b}$ & $5.43 \mathrm{~b}$ & $61.05 \mathrm{a}$ \\
\hline $\mathrm{C}_{2}=\mathrm{KSK}-133$ & $59.33 \mathrm{~b}$ & $308.00 \mathrm{~b}$ & $286.17 \mathrm{~b}$ & 95.99 & 20.90 a & $4.67 \mathrm{a}$ & $7.80 \mathrm{a}$ & $59.11 \mathrm{~b}$ \\
\hline LSD & 1.37 & 9.41 & 11.44 & NS & 0.49 & 0.15 & 0.41 & 1.94 \\
\hline
\end{tabular}

Any two means not sharing a letter in common within a column differ significantly at 5\% probability level.

\subsection{Total Tillers}

Total tillers are statistically differed among seeding density treatments as represented in Table 1. Maximum numbers of tillers (388.67) were observed at the seeding density of $75 \mathrm{~kg} \cdot \mathrm{ha}^{-1}\left(\mathrm{~S}_{4}\right)$. While minimum total tillers (244.83) were recorded for $S_{1}\left(30 \mathrm{~kg} \cdot \mathrm{ha}^{-1}\right)$. As for rice cultivars are concerned the KSK-133 showed lower number of total tillers (308.00) as compared to Super basmati which showed total number of tillers (332.33). A very strong positive correlation of total number of tillers with paddy yield was observed having more than $97 \%$ and 98\% determination of coefficient in Super basmati and KSK-133 for total tillers is observed as shown in Figure 5 . The greater number of tillers $\mathrm{m}^{-2}$ at $75 \mathrm{~kg} \cdot \mathrm{ha}^{-1}$ might be attributed to optimum plant population in direct sown rice which resulted in comparatively low inter-competition and better resources utilization at tillering stage. Rice cultivars were sown using high seed rate which ultimately resulted in higher number of tillers per unit area. These results are in consistent with [18] and [19] in which they mentioned that increase in seed rate can cause an increase in number of tillers.

\subsection{Productive Tillers}

Productive tillers are statistically differed among seeding density treatments as depicted in Table 1. Maximum 

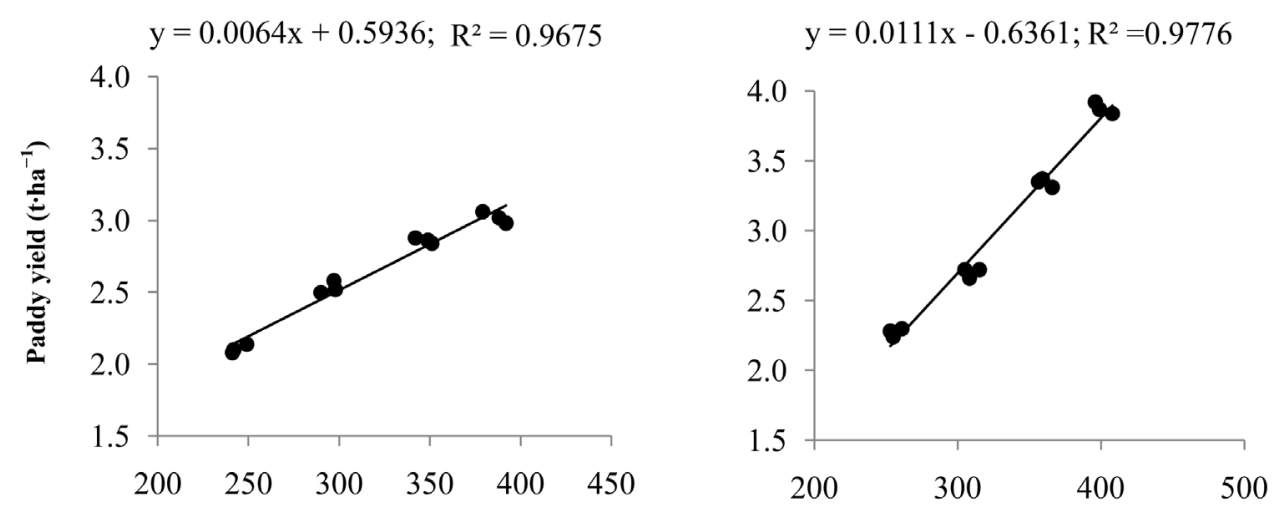

(a)

(b)

Figure 5. Relationship between total number of tillers $\left(\mathrm{m}^{2}\right)$ and paddy yield $\left(\mathrm{t} \cdot \mathrm{ha} \mathrm{a}^{-1}\right)$ in (a) Super basmati and (b) KSK-133.

productive tillers (369.50) were observed at the seeding density of $75 \mathrm{~kg} \cdot \mathrm{ha}^{-1}\left(\mathrm{~S}_{4}\right)$. While minimum productive tillers (221.33) were recorded for $S_{1}\left(30 \mathrm{~kg} \cdot \mathrm{ha}^{-1}\right)$. As for rice cultivars are concerned the KSK-133 showed less productive tillers (286.17) as compared to Super basmati which showed productive tillers (313.33). A very strong positive correlation of productive tillers with paddy yield was observed having more than $95 \%$ and $96 \%$ determination coefficient in Super basmati and KSK-133, is observed Figure 6. Greater number of productive tillers $\mathrm{m}^{-2}$ in at seeding density of $75 \mathrm{~kg} \cdot \mathrm{ha}^{-1}$ might also be attributed to optimum plant population due to higher initial seeding density $\mathrm{m}^{-2}$ in this treatment hence, more appropriation between the panicles for resource utilization which resulted in more number of fertile tillers per unit area. These results are supported by [20], [17] and [21] who reported that as seeding rate was increased, the panicle bearing tillers $\mathrm{m}^{-2}$ increased significantly.

\subsection{Kernels per Panicle}

Significant effect of various seeding densities on number of kernels per panicle was observed. Maximum number of kernels per panicle (102.43) was recorded at the seeding density of $30 \mathrm{~kg} \cdot \mathrm{ha}^{-1}\left(\mathrm{~S}_{1}\right)$ as shown in Table 1. While seeding density of $75 \mathrm{~kg} \cdot \mathrm{ha}^{-1}\left(\mathrm{~S}_{4}\right)$ produced minimum number of kernels per panicle (91.68). Super basmati produced more number of kernels per panicle (96.98) as compared to KSK-133 (95.99) when sown at the seeding density of $30 \mathrm{~kg} \cdot \mathrm{ha}^{-1}\left(\mathrm{~S}_{1}\right)$. A strong positive association was found between number of kernels per panicle and paddy yield having 90\% and 86\% determination coefficient in Super basmati and KSK-133 as shown in Figure 7. Greater number of kernels per panicle recorded at lower seeding densities might be due to greater availability of photosynthats due to less intra-plant competition, which resulted in better panicle development causing more appropriation and more number of kernels per panicle. These results are supported by [21] who reported maximum number of spikelets per panicle at the lower seeding densities.

\subsection{0-Kernel Weight}

Significant effect of various seeding densities on 1000-kernel weight was observed. Maximum 1000-kernel weight (19.35 g) was recorded at the seeding density of $30 \mathrm{~kg} \cdot \mathrm{ha}^{-1}\left(\mathrm{~S}_{1}\right)$ as shown in Table 1 . While seeding density of $75 \mathrm{~kg} \cdot \mathrm{ha}^{-1}\left(\mathrm{~S}_{4}\right)$ produced minimum 1000-kernel weight (17.93 g). Super basmati produced less 1000kernel weight (17.01) while maximum 1000-kernel weight (21.68 g) was recorded in KSK-133 when sown at the seeding density of $30 \mathrm{~kg} \cdot \mathrm{ha}^{-1}\left(\mathrm{~S}_{1}\right)$. In general, the KSK-133 had greater (20.90 g) 1000-kernel weight as compared to Super basmati (16.44 g). A strong positive association was found between 1000-kernel weight and paddy yield having 38\% and 75\% determination coefficient in Super basmati and KSK-133 for 1000-kernel weight as depicted in Figure 8. Higher 1000-kernel weight at lower seeding densities might be ascribed to less competition among productive tillers, more filling of starch in grains and better kernel development. The findings of the present study are supported by [21] who found that 1000-kernel weight was decreased with increase in seeding density. 


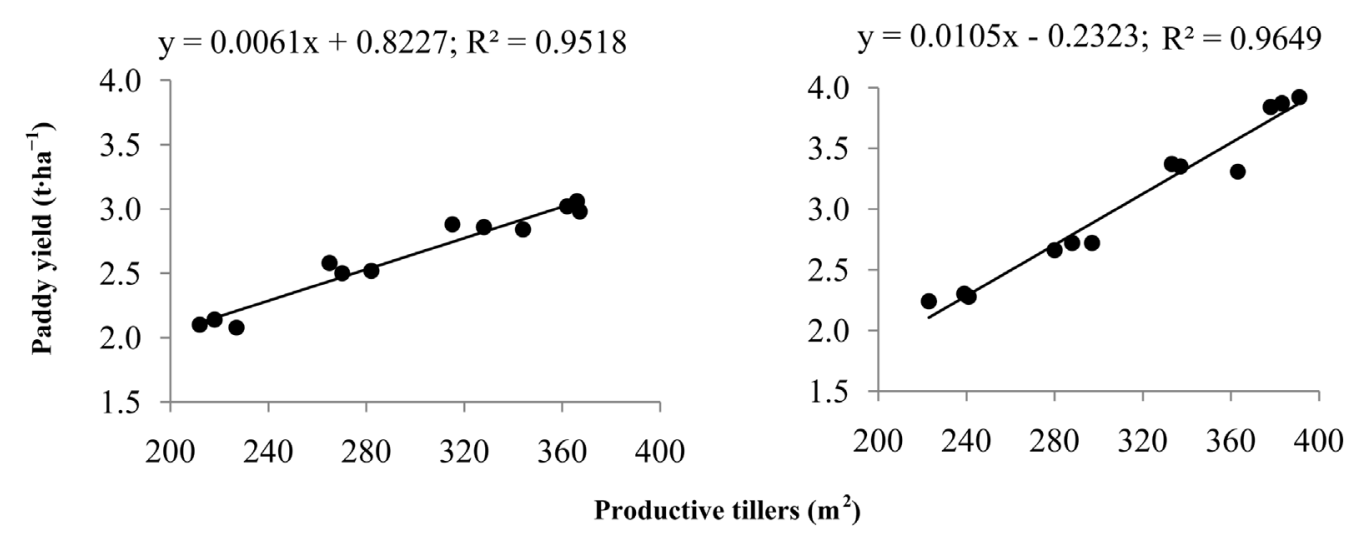

(a)

(b)

Figure 6. Relationship between productive tillers $\left(\mathrm{m}^{2}\right)$ and paddy yield $\left(\mathrm{t} \cdot \mathrm{ha}^{-1}\right)$ in (a) Super basmati and (b) KSK-133.
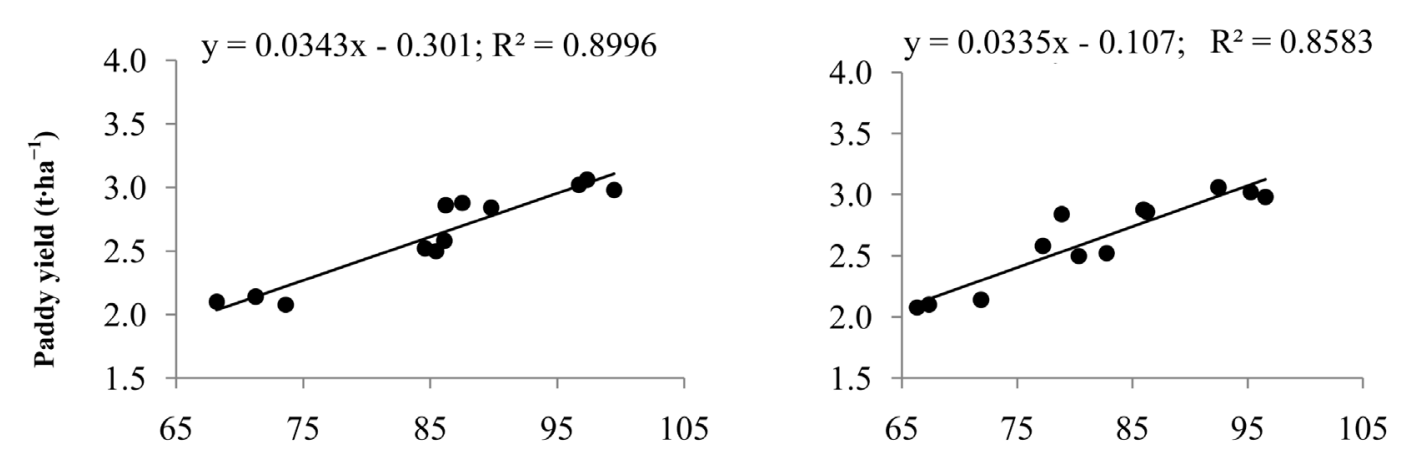

Number of kernels per panicle

(a)

(b)

Figure 7. Relationship between number of kernels per panicle and paddy yield ( $\mathrm{t} \cdot \mathrm{ha}^{-1}$ ) in (a) Super basmati and (b) KSK-133.
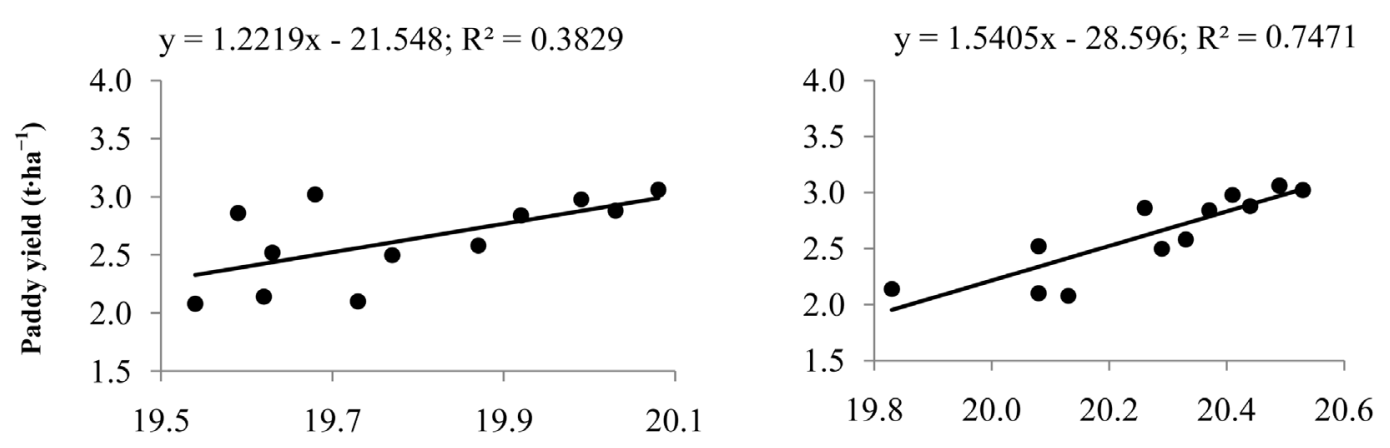

(a)

(b)

Figure 8. Relationship between 1000-kernel weight ( $\mathrm{g}$ ) and paddy yield $\left(\mathrm{t} \cdot \mathrm{ha}^{-1}\right.$ ) in (a) Super basmati and (b) KSK-133.

\subsection{Grain Yield (t·ha-1)}

A significant increase in paddy/grain yield was observed by increasing seeding density as shown in Table 1. 
Super basmati and KSK-133 produced higher paddy/grain yield (3.83 and $5.49 \mathrm{t}^{\mathrm{h}} \mathrm{ha}^{-1}$ ), respectively when sown at the seeding density of $75 \mathrm{~kg} \cdot \mathrm{ha}^{-1}\left(\mathrm{~S}_{4}\right)$. The response of both rice cultivars was similar to seeding density with respect to paddy/grain yield. There was a progressive increase in grain yield with each increase in seeding density. The paddy/grain yield of 3.17, 3.73, 4.37 and $4.66 \mathrm{t}^{\mathrm{h}} \mathrm{ha}^{-1}$ was recorded under the seeding densities of 30,45 , 60 and $75 \mathrm{~kg} \cdot \mathrm{ha}^{-1}$, respectively. The interaction between rice cultivars and seeding densities was also significant as depicted in Figure 9. KSK-133 produced more grain yield (4.67 tha ${ }^{-1}$ ) as compared to Super basmati (3.29 $\mathrm{t} \cdot \mathrm{ha}^{-1}$ ). Higher grain yield at $75 \mathrm{~kg} \cdot \mathrm{ha}^{-1}$ might be due to higher number of panicle bearing tillers $\mathrm{m}^{-2}$. Higher final kernel yield at the seeding density of $75 \mathrm{~kg} \cdot \mathrm{ha}^{-1}$ was due to higher panicle density per unit area in this treatment. Similar results have been reported by [22] and [23] reported that higher seeding densities decreased grain yield and optimum seed rate appeared to be 75 to $100 \mathrm{~kg} \cdot \mathrm{ha}^{-1}$.

\subsection{Normal Kernels}

Normal kernels percentage significantly affected by different seeding densities. Super basmati and KSK-133 showed maximum normal kernel percentage (64.41 and 61.68), respectively when sown at the seeding density of $30 \mathrm{~kg} \cdot \mathrm{ha}^{-1}$. Among seeding density treatments, maximum percentage of normal kernels (63.05) was recorded for $S_{1}\left(30 \mathrm{~kg} \cdot \mathrm{ha}^{-1}\right)$ against the minimum (57.75) at the seeding density of $75 \mathrm{~kg} \cdot \mathrm{ha}^{-1}$. The KSK-133 showed lower normal kernel percentage (59.11) as compared to Super basmati (61.05). The higher percentage of normal kernels recorded for $S_{1}$ might be attributed to less competition and better utilization of resources at grain filling stage. These results are in line with those of [21] who reported lower percentage of normal kernels at higher seeding densities.

\subsection{Sterile Kernels}

Sterility percentage was significantly affected by seeding densities. Seeding density of $75 \mathrm{~kg} \cdot \mathrm{ha}^{-1}\left(\mathrm{~S}_{4}\right)$ showed highest sterility percentage (6.10 and 9.12) as against the sterility percentage of (4.69 and 6.32$)$ at $30 \mathrm{~kg} \cdot \mathrm{ha}^{-1}\left(\mathrm{~S}_{1}\right)$ in Super basmati and KSK-133, respectively. The interaction between rice cultivars and seeding densities was also significant as shown in Figure 10. The KSK-133 produced maximum percentage of sterile spikelets (9.12) at the seeding density of $75 \mathrm{~kg} \cdot \mathrm{ha}^{-1}\left(\mathrm{~S}_{4}\right)$. The Super basmati showed lower sterility percentage (5.43) as compared to sterility percentage of (7.80) for KSK-133. Higher percentage of sterile spikelets recorded for $\mathrm{S}_{4}$ was attributed to dense population which caused severe competition for photosynthats at reproductive stage and resulted in high sterility of spikelets particularly at lower location of panicle. The findings of the present study are in line with those of [9] who reported that percentage of sterile spikelets increased by increasing seeding density.

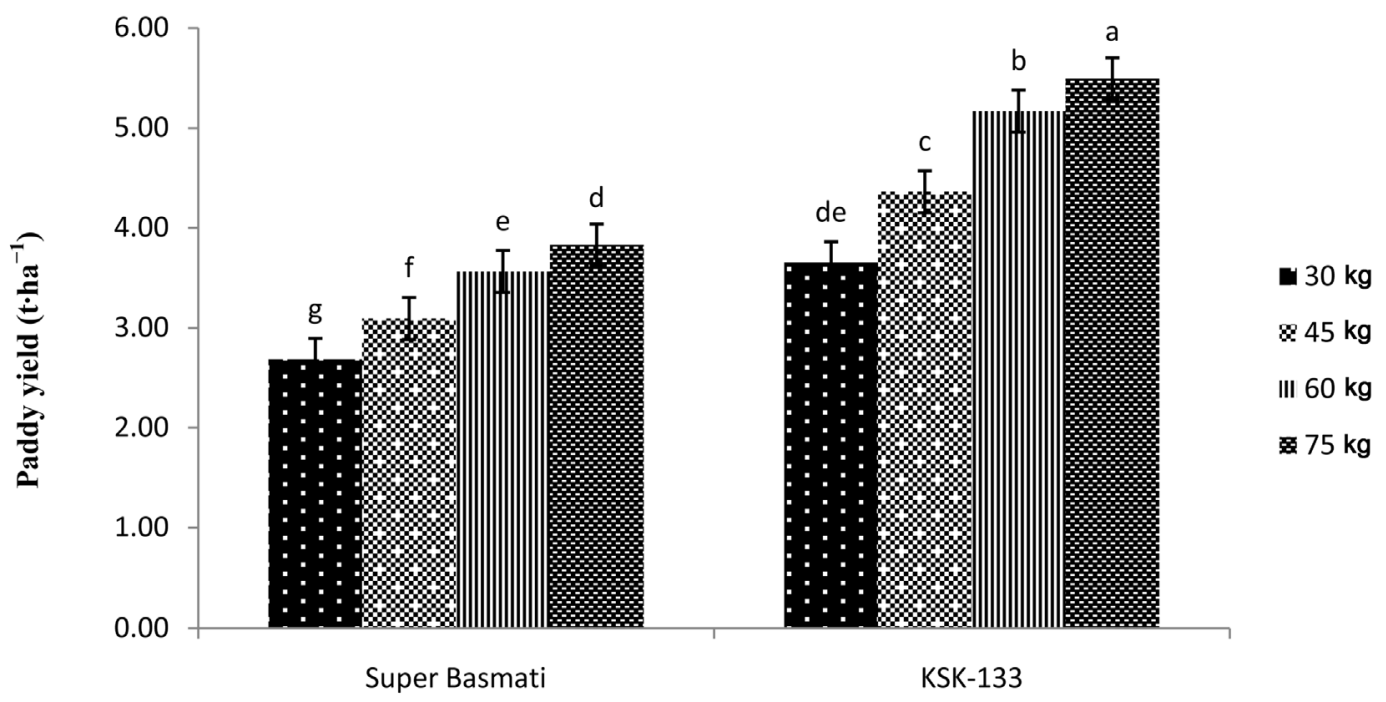

Figure 9. Interactive effect of seeding densities and rice cultivars on paddy yield $\left(\mathrm{t} \cdot \mathrm{ha}^{-1}\right)$ in direct seeded rice. Vertical bar above mean denotes LSD value. Any two treatments not sharing a letter in common differ significantly at $5 \%$ probability level. 


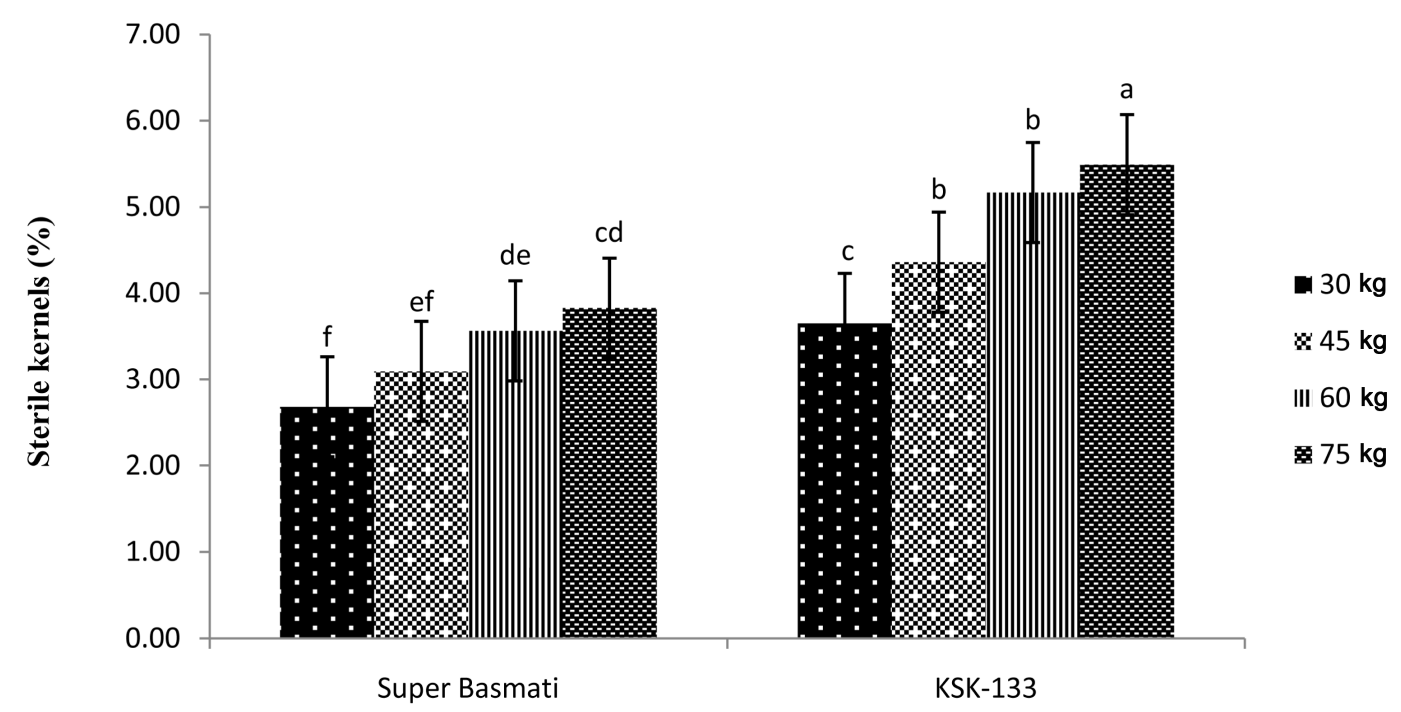

Figure 10. Interactive effect of seeding densities and rice cultivars on sterile kernels (\%) in direct seeded rice. Vertical bar above mean denotes LSD value. Any two treatments not sharing a letter in common differ significantly at $5 \%$ probability level.

\section{Conclusion}

It is concluded that using seeding density of $75 \mathrm{~kg} \cdot \mathrm{ha}^{-1}$ for direct seeded coarse and fine rice is beneficial in terms of better growth and higher yield but kernel quality is reduced by increasing seeding density.

\section{References}

[1] Bhambhro, S.A. (2001) Plant Hopper a Serious Threat to Rice Crop in Upper Sindh. The Daily Dawn. Economic and Business Review, III.

[2] Anonymous (2009) Biology of Rice. Series of Crop Specific Biology Documents. Department of Biotechnology, Ministry of Science and Technology, India, 1-2.

[3] Anonymous (2012) Pakistan Economic Survey, 2011-12. Economic Advisor’s Wing, Finance Division, Islamabad, 20-21.

[4] Gill, M.A. and Rehman, H.M.U. (2002) Parachute Rice Transplanting Technology: An Economical Alternative to a Traditional Practice. Pakistan Agricultural Research Council, on Farm Water Management, Rice-Wheat Consortium for the Indo-Gangetic Plains. Facilitated by Block, C.G., National Agriculture Science Centre (NASC) Complex, DPS Marg, Pusa Campus, New Delhi.

[5] Khaliq, A. and Matloob, A. (2011) Weed Crop Competition Period in Three Fine Rice Cultivars under Direct Seeded Rice Culture. Pakistan Journal of Weed Science Research, 17, 229-243.

[6] Hashimoto, Y., Izumida, M., Sakal, R., Otsaki and Hanayama, H. (1978) Results of Experiments on Sowing of Paddy Rice Using Machines in Cooperation with Farmers. Proceedings of Crop Science Society of Japan, 26, 35-38.

[7] Ahmad, S., Hussain, A., Aki, H. and Ahmad, A. (2005) Transplanted Fine Rice (Oryza sativa L.) Productivity as Affected by Plant Density and Irrigation Regimes. International Journal of Agriculture and Biology, 7, 445-447.

[8] Janoria, M.P. (1989) A Basic Plant Ideoptype for Rice. International Rice Research Newsletter, 14, 12-13.

[9] Akbar, N. and Ehsanullah (2004) Agro-Qualitative Responses of Direct Seeded Fine Rice to Different Seeding Densities. Pakistan Journal of Agricultural Science, 41, 1-2.

[10] Chaudhry, A.M. and Iqbal, M.S. (1986) Production Technology for Basmati-385. Progressive Farming, 16, 17-24.

[11] Miller, B.C., Hill, J.E. and Roberts, S.R. (1991) Plant Population Effects on Growth and Yield in Water Seeded Rice. Agronomy Journal, 83, 291-297. http://dx.doi.org/10.2134/agronj1991.00021962008300020006x

[12] Uzun, A., Bilgili, U., Sincik, M. and Acıkgoz, E. (2004) Effects of Seeding Rates on Yield and Yield Components of Hungarian Vetch (Vicia pannonica Crantz.). Turkish Journal of Agriculture and Forestry, 28, 179-182.

[13] Steel, R.G.D., Torrie, J.H. and Dickey, D. (1997) Principles and Procedures of Statistics: A Biometrical Approach. 3rd Edition, McGraw Hill Book Co. Inc., New York, 172-177. 
[14] Hu, W.H., Qi, Y.J., Sun, M.C. and Guan, S.Y. (2000) Photosynthetic Characters of Sparsely Populated Rice. Journal of Jilin Agricultural University, 22, 11-14.

[15] Janaki, P. and Thiyagarajan, T.M. (2005) Effect of Nitrogen Management Approaches and Planting Densities on Nitrogen Accumulation by Transplanted Rice. Acta Agronomica Hungarica, 53, 405-415. http://dx.doi.org/10.1556/AAgr.53.2005.4.6

[16] Akita, K. (1982) Effect of Plant Density on Characters, Growing Organs and Yield Components of Rice. Science Reports of Faculty of Agriculture, Vol. 15, Kobe University, Kobe, 5-21.

[17] Sharma, A.R. (1994) Effect of Seed Rate and Row Spacing on the Performance of Early and Late Maturing Rice Cultivars in Mixed Crop Systems under Intermediate Deep Water Conditions (15 - $50 \mathrm{~cm}$ ). Journal of Agricultural Science, 122, 201-205. http://dx.doi.org/10.1017/S0021859600087372

[18] Phuong, L.T., Denich, M., Vlek, P.L.G. and Balasubramanian, V. (2005) Suppressing Weeds in Direct-Seeded Lowland Rice: Effects of Methods and Rates of Seeding. Journal of Agronomy and Crop Science, 191, 185-194. http://dx.doi.org/10.1111/j.1439-037X.2005.00151.X

[19] Chauhan, B.S., Singh, V.P., Kumar, A. and Johnson, D.E. (2011) Relations of Rice Seeding Rates to Crop and Weed Growth in Aerobic Rice. Field Crops Research, 121, 105-115. http://dx.doi.org/10.1016/j.fcr.2010.11.019

[20] Pedroso, B.A. and Mariot, C. (1986) Sowing Density and Spacing between Rows. Instituto Rio Grandense do Arroz, 165-168.

[21] Aslam, M., Shah, S.H. and Nazir, M.S. (2002) Biological Response of Direct-Seeded Course Rice to Seeding Density and Planting Time. Pakistan Journal of Agricultural Sciences, 39, 12-14.

[22] Morales, O., Avila, C. and Cruz, F. (1984) Influence of Rates of Nitrogen and Sowing Rates on Four Cultivars of Rice. Ciencia y Tecnica en la Agricultura Arroz, 7, 111-127.

[23] Lal, S. (1986) Seed Rate for Direct Seeded Rice. Indian Farming, 36, 19-21. 
Scientific Research Publishing (SCIRP) is one of the largest Open Access journal publishers. It is currently publishing more than 200 open access, online, peer-reviewed journals covering a wide range of academic disciplines. SCIRP serves the worldwide academic communities and contributes to the progress and application of science with its publication.

Other selected journals from SCIRP are listed as below. Submit your manuscript to us via either submit@scirp.org or Online Submission Portal.
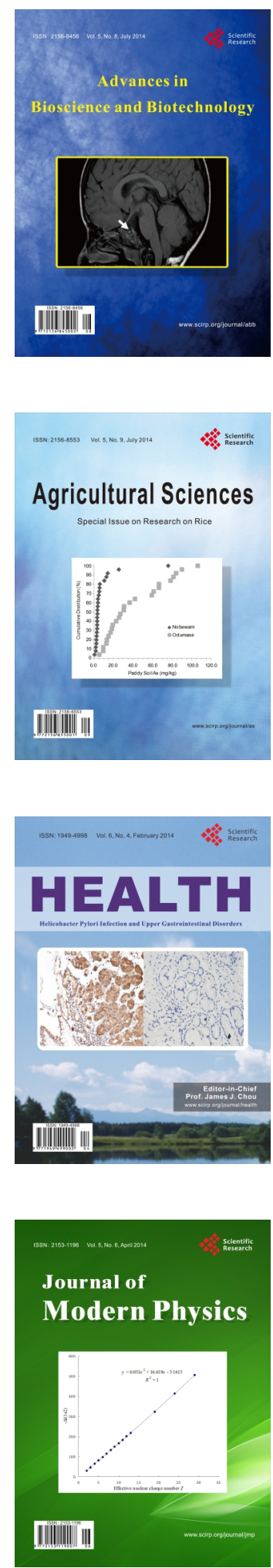
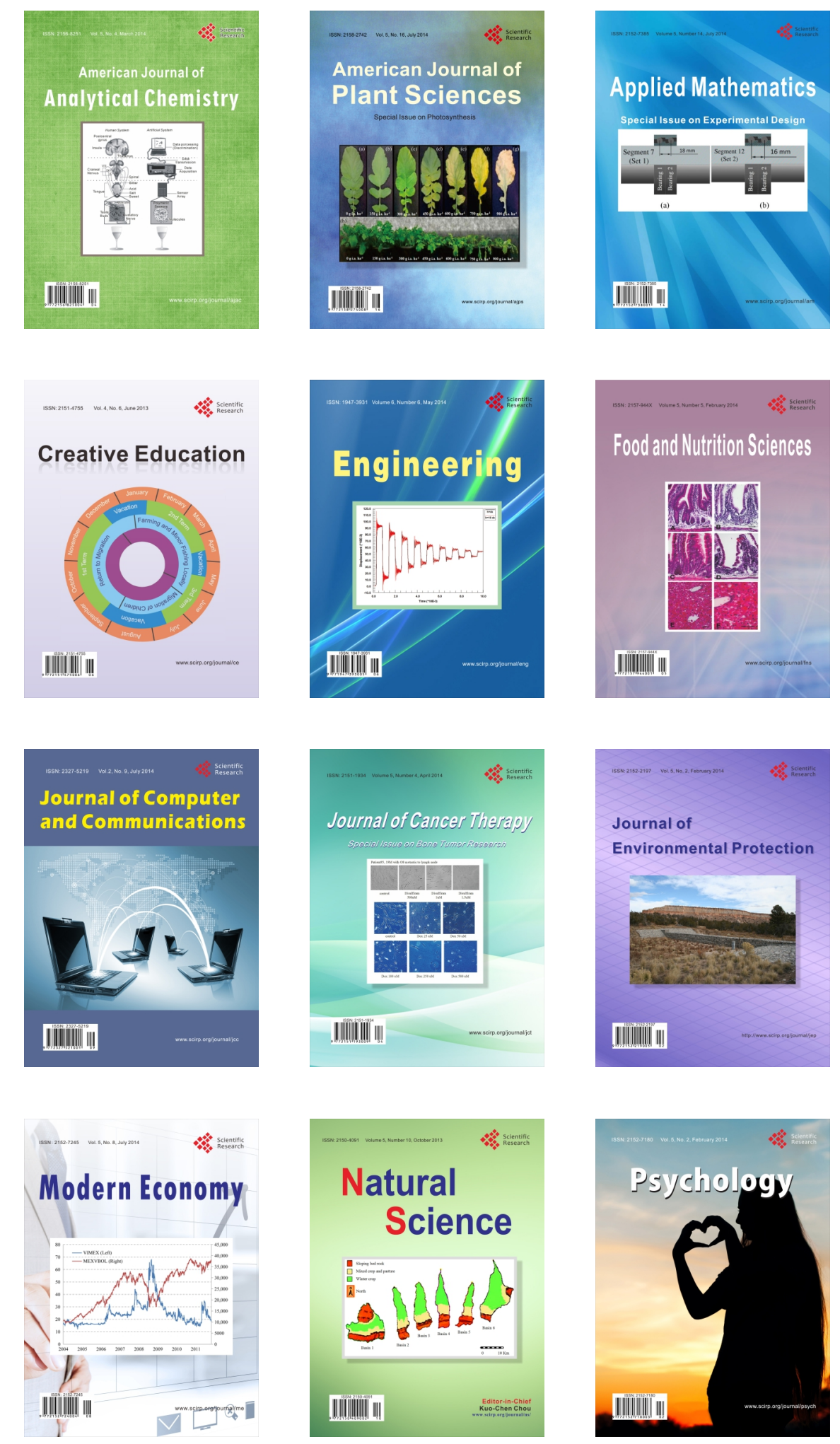